\title{
CHANGES IN THE FREQUENCY AND SEVERITY OF HYDROLOGICAL DROUGHTS OVER ETHIOPIA FROM 1960 TO 2013
}

\author{
A.M. EL KENAWY ${ }^{1 *}$, M.F. MCCABE ${ }^{2}$, \\ S.M. VICENTE-SERRANO ${ }^{3}$, J.I. LÓPEZ-MORENO ${ }^{3}$, S.M. ROBAA ${ }^{4}$
}

\begin{abstract}
${ }^{1}$ Department of Geography, Mansoura University, Mansoura, Egypt. ${ }^{2}$ Division of Biological and Environmental Sciences and Engineering, King Abdullah University of Science and Technology, Thuwal, Saudi Arabia. ${ }^{3}$ Instituto Pirenaico de Ecología, Spanish National Research Council (IPE-CSIC), Spain.
\end{abstract} ${ }^{4}$ Department of Astronomy, Space Science and Meteorology, Faculty of Science - Cairo University, Egypt.

\begin{abstract}
Here we present an analysis of drought occurrence and variability in Ethiopia, based on the monthly precipitation data from the Climate Research Unit (CRU-v3.22) over the period from 1960 to 2013. The drought events were characterized by means of the Standardized Precipitation Index (SPI) applied to precipitation data at a temporal scale of 12 months. At the national scale, the results reveal a statistically significant decrease in the severity of droughts over the 54-year period, a pattern that is mostly attributed to a statistically significant decrease in the frequency of high intensity drought episodes (i.e., extreme and very extreme droughts), compared to moderate droughts. To assess the general patterns of drought evolution, a principal component analysis (PCA) was applied to the SPI series. PCA results indicate a high spatial heterogeneity in the SPI variations over the investigated period, with ten different spatially well-defined regions identified. These PCA components accounted for $72.9 \%$ of the total variance of drought in the region. These regions also showed considerable differences in the temporal variability of drought, as most of the regions exhibited an increase in wetness conditions in recent decades. In contrast, the regions that receive less than $400 \mathrm{~mm}$ of annual precipitation showed a declining trend, with the largest changes occurring over Afar region. Generally, the highly elevated regions over the central Ethiopian Highlands showed the weakest changes, compared to the lowlands. This study confirms the local character of drought evolution over Ethiopia, providing evidence for policy makers to adopt appropriate local policies to cope with the risks of drought. Over Ethiopia, the detailed spatial assessment of drought evolution is required for a better understanding of the possible impacts of recurrent drought on agriculture, food production, soil degradation, human settlements and migrations, as well as energy production and water resources management across Ethiopia.
\end{abstract}




\section{Cambios en la frecuencia y severidad en las sequías hidrológicas de Etiopía entre 1960 y 2013}

RESUMEN. Se presenta un análisis de la ocurrencia y variabilidad de sequías en Etiopía, basado en datos de precipitación mensual de la Climate Research Unit (CRU-v3.22) para el periodo entre 1960 y 2013. Los eventos de sequía se caracterizaron por medio del Índice de Precipitación Estandarizada (SPI) aplicado a los datos de precipitación para una escala temporal de 12 meses. A escala nacional, los resultados revelan un descenso estadísticamente significativo en la severidad de las sequías en un periodo de 54 años, un patrón que se atribuye principalmente al descenso en la frecuencia de episodios de sequía de elevada intensidad. Para comprobar los patrones generales de evolución de sequías se aplicó un análisis de componentes principales (PCA) a las series de SPI. Los resultados del PCA indican una alta heterogeneidad espacial en las variaciones del SPI durante el periodo investigado, habiéndose identificado diez regiones espacialmente diferentes. Los componentes del PCA representaron el $72.9 \%$ de la varianza total de sequías en la región. Estas regiones también mostraron un aumento en las condiciones de humedad en décadas recientes. En contraste, las regiones que reciben menos de $400 \mathrm{~mm}$ de precipitación anual mostraron una tendencia decreciente, siendo la región de Afar la que presenta los mayores cambios. En general, las regiones más elevadas de las tierras altas del centro de Etiopía son las que mostraron menores cambios en comparación con las tierras bajas. Este estudio confirma el carácter local de la evolución de las sequías en Etiopía, proporcionando evidencias para los políticos y técnicos con el fin de adoptar políticas locales apropiadas para enfrentarse a los riesgos de sequías. En Etiopía, se requiere un estudio especial detallado de la evolución de las sequías para una mayor comprensión de los posibles impactos de sequías recurrentes sobre la agricultura, la producción de alimento, la degradación del suelo, los asentamientos humanos y las migraciones, así como la producción de energía y las gestión de los recursos hídricos en Etiopía.

Key words: drought, Standardized Precipitation Index, precipitation, variability, trends, Principal Component Analysis, Ethiopia.

Palabras clave: sequía, Índice de Precipitación Estandarizada, precipitación, variabilidad, tendencias, Análisis de Componentes Principales, Etiopía.

Received 10 January 2016 Accepted 12 February 2016

*Corresponding author: A.M. El Kenawy, Department of Geography, Mansoura University, Mansoura, Egypt. E-mail: kenawy@mans.edu.eg

\section{Introduction}

Drought is a climate phenomenon of importance across a range of disciplines, with implications and impacts in hydrological, agricultural and environmental applications (Brando et al., 2014; Hunt et al., 2014). In the context of global warming, the occurrence, frequency, strength and influence of drought have been the focus of recent climate research 
(e.g., Sheffield et al., 2012; Dai, 2013; Hunt et al., 2014; Vicente-Serrano et al., 2015a). A number of these studies have presented an evidence of the upward tendency of the frequency and intensity of drought across many regions (e.g., Glantz, 2001; Santos et al., 2010; Vicente-Serrano et al., 2015a). Although Sheffield et al. (2012) have suggested little change in the global drought over the past 60 years, other research has also highlighted the potential implications of future climate changes on drought frequency and severity (Sheffield and Wood, 2008; Dai, 2011), with changes likely to enhance land degradation, particularly in arid and semi-arid regions (Vicente-Serrano et al., 2015b).

The evolution of drought is determined mainly by changes in precipitation: a climate variable that shows a generally low spatial coherence in trends on hemispheric, continental, regional and even local scales (Schonwiese and Rapp, 1997; Williams et al., 2012; Ren et al., 2013; Westra et al., 2013). One pertinent example is Schonwiese and Rapp (1997), who noted regional differences in precipitation trends over Europe, with a general increase occurring in the north and a decrease in the south. Over Africa, numerous studies have reported a significant decrease in rainfall amounts across vast parts of the continent (e.g., Meinke et al., 2005; Hoerling et al., 2006; Ngongondo et al., 2011; Williams et al., 2012) For example, Williams et al. (2012) noted a decline in June-September (JJAS) precipitation over the African Horn during the past half century. In contrast, other studies indicate no changes in rainfall totals for some regions (Seleshi and Zanke, 2004). Accordingly, temporal evolution and spatial variations of drought require examination at a more detailed spatial scale (e.g., regional or local scales). Assessing drought characteristics at finer spatial scales is also motivated by the notion that the impact of drought on ecosystems and societies is complex, in the sense that a particular drought severity may have different consequences in different regions, as a consequence of the varying vulnerabilities of these regions (AntwiAgyei et al., 2012; Vicente-Serrano et al., 2012).

Over Africa, drought is one of the most important of potential natural disasters. Combined with high consumption and low water quality, droughts exacerbate already challenging water scarcity related issues (Mishra and Singh, 2010). Among the African regions, East Africa is frequently portrayed as a drought-stricken region. A catastrophic drought occurred in the region in 1984, which killed an estimated 450,000 people in Ethiopia and Sudan. More recently, a severe drought in Somalia and southern Ethiopia in June 2011 resulted in more than 10 million people seeking humanitarian aid, as well as 380,000 refugees impacting neighboring countries (Vicente-Serrano et al., 2012). Over Ethiopia, a highly populated country whose economy largely depends on rain-fed agriculture, drought is a recurrent climate phenomenon, with a frequency of occurrence approaching one event per decade (Gebrehiwot et al., 2011). Such drought events are often associated with severe economic losses, reduction in GDP growth, crop failure and impact livestock rearing and mortality. According to Meze-Hausken (2004), many farms have shifted to more droughtresistant crops in northern Ethiopia, as a consequence of the decline in rainfall during the last decades. The impact of drought on water resources is also evident, particularly in the most populated areas (e.g., the Rift Valley and the central Ethiopian highlands), where access to water supplies is limited (Funk et al., 2005).

While a number of earlier studies have assessed drought variability over Ethiopia, the spatial and temporal variability of drought is neither well-established nor understood, 
especially at the regional and sub-regional scales. This aspect is particularly relevant as many such drought studies tend to focus on either a short-term analysis (e.g., Bewket and Conway, 2007), particular seasons (e.g., Viste et al., 2013), defined drought events (e.g., Viste et al., 2013) or specific regions rather than the whole country (e.g., Meze-Hausken, 2004; Bewket and Conway, 2007; Edossa et al., 2010; Gebrehiwot et al., 2011). For example, Viste et al. (2013) found a significant increase in the frequency of spring drought over Ethiopia during the period 1972-2011, albeit with a stronger tendency over lowlands compared to central and northern Highlands. Also, Gebrehiwot et al. (2011) employed precipitation and remotely sensed data to assess spatial and temporal variability of drought in semi-arid and arid regions of Northern Ethiopia. They demonstrated that the eastern and southern areas of the Tigray region suffered from a recurrent cycle of drought over the last decade. Similarly, Edossa et al. (2010) assessed spatial and temporal variability of meteorological and hydrological droughts in the Awash River Basin, suggesting that the most severe drought events occurred frequently in the Upper and Middle Awash Basin. Complementing these previous works, our study provides the first comprehensive attempt to characterize long-term drought characteristics over Ethiopia at local and regional scales, allowing for the differentiation of drought variability across the entire country. This detailed assessment is demanded due to the high seasonality and the high degree of spatial variability of the Ethiopian precipitation, which are also driven by various geographic variables (e.g., topography) and atmospheric processes (e.g., Indian and tropical configurations). Also, recalling that the impacts of drought depend largely on the severity, duration and spatial extent of the rainfall deficit, assessing the spatial and temporal characteristics of drought is important not only for accurate quantification of its socioeconomic impacts, but for informing and improving forecasting and early warning systems as well (Boken, 2009; Sheffield et al., 2014). This detailed assessment has also implications across a wide range of natural and human environments, including agriculture, water resources, biodiversity, health and food production. Furthermore, given that the Ethiopian Highlands contribute to more than $85 \%$ of the Nile discharge, the negative impacts of drought over Ethiopia, potentially accelerated by rapid climate change, may extend beyond the borders of the country to other water-stressed countries in the lower catchment of the Nile Basin (e.g., Egypt and Sudan). These impacts may further limit water supplies to these countries and increasing the risk of national conflicts and political instability (Burke et al., 2009).

The overall objective of our research is to examine the spatial and temporal changes in the severity and frequency of drought over Ethiopia, as described by the Standardized Precipitation Index (SPI), for the period 1960-2013. Ethiopia is a country of high geographic and climatic diversity, which makes it a unique site to assess the possible impacts of recent climate change on drought characteristics (e.g., intensity, severity and spatial extent of occurrence) (Trenberth et al., 2014). These changes could have serious impacts on society, environment, and economy in Ethiopia and neighboring countries (e.g., Sudan and Egypt).

\section{Study region}

Ethiopia is a landlocked country situated in the Horn of Africa; with an area of approximately $1.12 \times 10^{6} \mathrm{~km}^{2}$ contained between latitudes $7^{\circ} 57^{\prime}$ and $14^{\circ} 53^{\prime} \mathrm{N}$, and longitudes of $33^{\circ}$ and $48^{\circ} \mathrm{E}$. Ethiopia is markedly heterogeneous, with altitudes varying 
from about 100m below mean sea level (the Dalol Depression, Northeastern Lowlands) to nearly 4550 m (Ras Dejen mount, Northern Highlands) (Figure 1). The East African Rift Valley crosses the country on a northeast-southwest axis. The climate in Ethiopia is very diverse, with almost 10 climate classes following the Köppen-Geiger's scheme. Of these, the dominant climate types are the arid, hot steppe (BSh), the tropical monsoon (Am) and temperate humid warm summer (Cfb). The eastern slopes of the Ethiopian Highlands exhibit a temperate dry summer (Cs) climate, while the western slopes have a temperate dry winter (Cw) climate (Peel et al., 2007). The average annual temperature (1981-2010) is $22.5^{\circ} \mathrm{C}$, with the peak in late spring or early summer (March-June). As shown in Figure 1, the coldest temperatures are recorded over mountainous regions in the center, north and northeast, while the warmest temperatures are generally found in the lowlands of the northeast and southeast. As shown in Figure 2, rainfall amounts are characterized by strong seasonality and high spatial variability. According to Diro et al. (2008), three different rainy seasons can be distinguished in Ethiopia: (1) February to May (Belg), (2) June to September (Kiremt), and (3) October to January (Bega). Most of the rainfall in the region occurs during the Kiremt season, with the November-February period generally representing the driest months. As illustrated in Figure 1, the annual rainfall totals range from $100-150 \mathrm{~mm}$ in arid and semi-arid NE lowlands to more than $1700 \mathrm{~mm}$ in the southwest region (Griffiths, 1972; Korecha and Barnston, 2007). Rainfall in the region is largely impacted by the latitudinal migration of the Red Sea Trough (RST), which moves to the north of the equator during summer and to the northern hemisphere during spring (Deng et al., 2015). The study domain is also influenced by the tropical and extratropical atmospheric circulations (e.g., ENSO), as well as the Indian monsoon system that brings substantial moisture from the Indian Ocean into the region (Beltrando and Camberlin, 1993). Rainfall events are also intensified during June-September, due to the northern most shift of the Inter-Tropical Convergence Zone (ITCZ), which brings the African monsoon (Schneider et al., 2014).

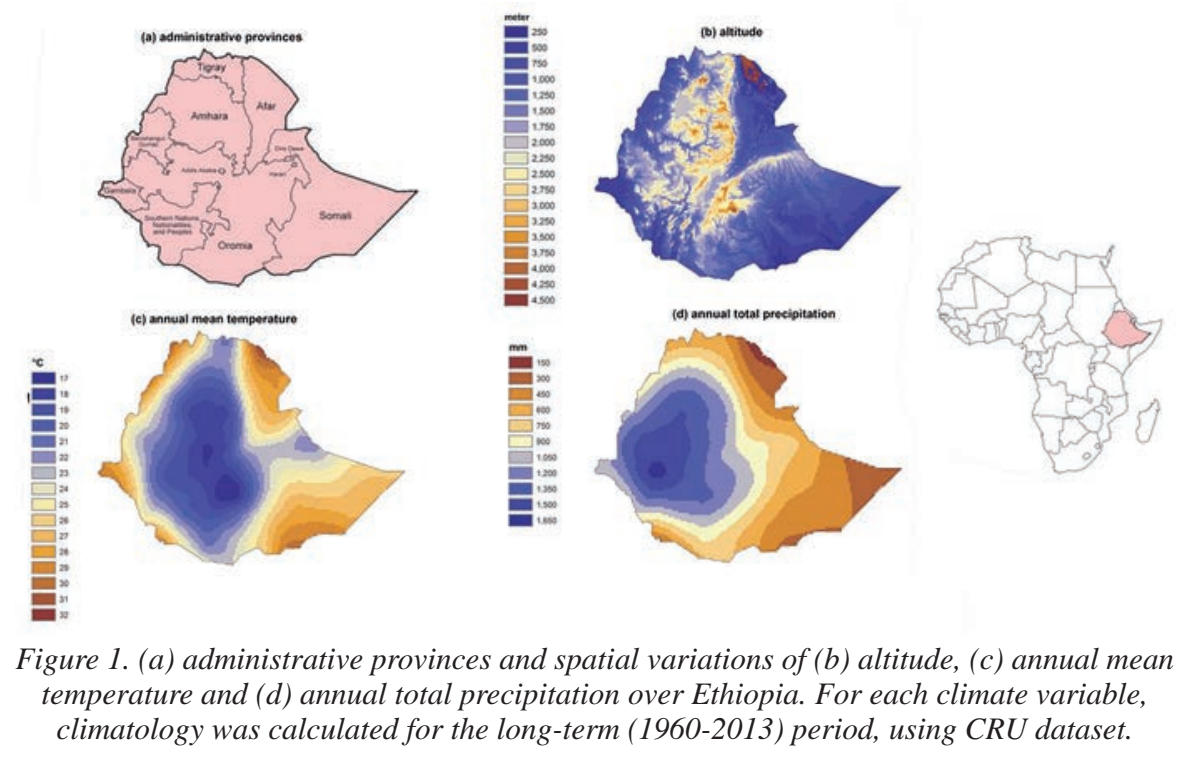



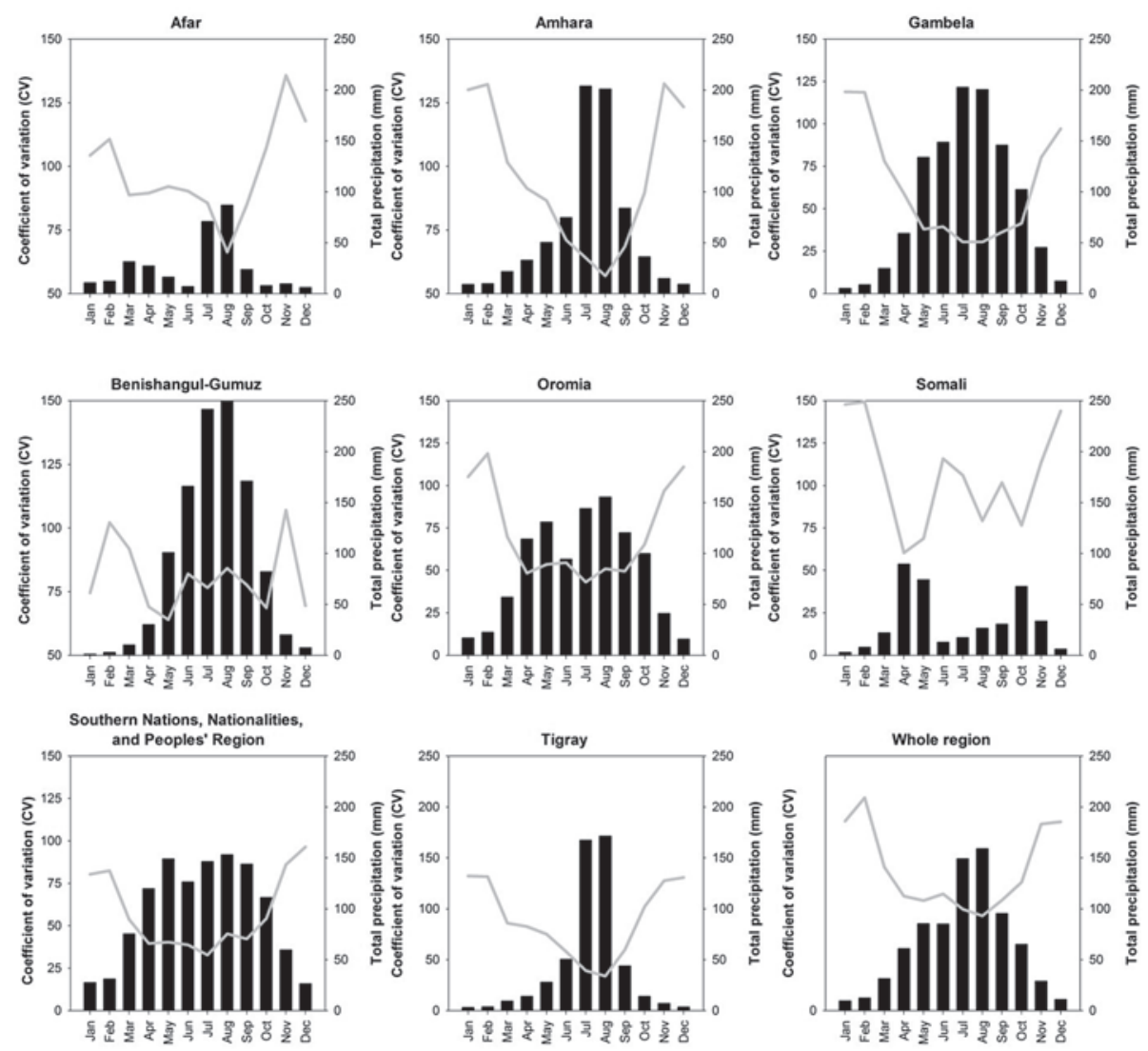

Figure 2. Seasonal cycle of total precipitation $(\mathrm{mm})$ and coefficient of variation $(\mathrm{CV})$ calculated for the different regions over Ethiopia. All calculations are made based on the CRU data for the period 1960-2013.

\section{Data and methods}

\subsection{Data}

In order to determine the spatial variations and evolution of drought at a fine spatial scale over Ethiopia, high quality, long-term and spatially dense precipitation data are required. The current network of rain gauges over the region suffers from an uneven spatial distribution and fragmentation, which makes the assessment of drought characteristics a challenging task (Viste et al., 2013). The strong seasonality of rainfall, combined with complex orography and an overall low density of observatories, adds additional complexity to drought calculation via observational data. With the development of modern observation and massive computing technologies, the estimation of climatic variables (e.g., precipitation) based on a combination of multi-source data products helps to obtain more reliable data, particularly in areas where long-term reliable 
observation data is not available or gauge are sparse. In this regard, gauge-based gridded precipitation products are often used by the scientific community due to their spatial and temporal continuity and availability for extended periods. In this work, we employed the updated Climate Research Unit (CRU) version 3.22 rainfall data to characterize drought in Ethiopia. CRU (v.3.22) is a monthly gridded data set provided by the East Anglia University (UK) that is produced on a $0.5^{\circ} \times 0.5^{\circ}$ global grid for the period 1901-2013 (Harris et al., 2014). This dataset was compiled from monthly rainfall observations at meteorological stations across the global land areas, providing anomalies from a 1961 to 1990 mean and allowing absolute monthly values to be obtained when combined with the climatology (Harris et al., 2014). CRU data (v3.22) have been validated against in situ observations in many regions worldwide, confirming their reliability (e.g., El Kenawy and McCabe, 2015; Livneh et al., 2015; Stagge et al., 2015). Accordingly, this dataset can provide valuable information on relatively reasonable spatial and temporal resolutions for assessment of current droughts and their impacts in the region. Here, we constrained our analysis to the period 1960-2013 to minimize the possible influence of year to year variations in the number of observatories used for interpolating CRU (v.3.22) data. Changes in station networks over space and time can introduce anomalous data and spurious variability into precipitation data, particularly in earlier decades.

\subsection{Drought calculation}

A large number of indices have been developed to quantify drought, including the Palmer Drought Severity Index [PDSI], Crop Moisture Index [CMI], Agro-hydro Potential [AP], Surface Water Supply Index [SWSI], Soil Moisture Deficit Index (SMDI), Evapotranspiration Deficit Index (ETDI), Normalized Difference Vegetations Index [NDVI], Standardized Precipitation Index [SPI] and the Standardized Precipitation Evapotranspiration Index [SPEI] (Mishra and Singh, 2010; Sheffield and Wood, 2011). In all the indices, precipitation is the common climate variables for drought monitoring and assessment. In this work, we selected the SPI for drought calculation using the monthly precipitation data at each grid cell for the 54-year study period. The SPI was proposed by McKee et al. (1993), and has been used frequently during the two last decades (e.g., Lloyd-Hughes and Saunders, 2002; Vicente-Serrano, 2006; Hirschi et al., 2011; VicenteSerrano et al., 2015a). In addition to its simplicity and ease of calculation, SPI is suitable for spatial representation of drought variability in regions of complex topography and climate, as it is a normalized index that accounts for comparison between different areas (Lloyd-Hughes and Saunders, 2002). The SPI is based on the conversion of precipitation data to probabilities based on long-term precipitation records computed on different time scales. Probabilities are transformed into standardized series with an average of 0 and a standard deviation of 1 . Among the different cumulative probability distributions used to fit the precipitation series, the Pearson III distribution shows enhanced adaptability to precipitation series at different time scales (Vicente-Serrano, 2006; Quiring, 2009). Here, we used the algorithm described by Vicente-Serrano (2006) to calculate the SPI values based on the Pearson III distribution and L-moments approach to obtain the distribution parameters. In this regard, the Pearson III distribution is preferred to other models (e.g., Gamma), because it is described using three different parameters (scale, shape 
and location) (Santos et al., 2010). Based on a comparison of different drought indices, Ntale and Gan (2003) found that the SPI was the best index to characterize droughts in East Africa, but after fitting precipitation data to the Pearson type III distribution rather than gamma distribution. As SPI can be generated for different time scales based on the requirement of monthly, seasonal, or long-term drought assessment, we calculated the SPI at a temporal resolution of 12 consecutive months, as this temporal scale is more closely associated with hydrological droughts. In addition, this scale indicates long-term trends in precipitation. Over Ethiopia, the rainfed agriculture is the primary source of national income as well as the main consumer of water. Accordingly, it is likely that the economy can be impacted by the hydrological droughts, as summarized by the SPI12 timescale. Furthermore, hydrological droughts over Ethiopia could have detrimental effects on many hydrological aspects (e.g., water availability) over the lower tributaries of the Nile Basin. In this study, we also estimated the surface area represented by each drought class, following the drought intensity scheme described in Agnew (2000) (Table 1). Due to its simplicity, this classification scheme has been widely applied in a number of drought studies (e.g., Vicente-Serrano and Cuadrat-Prats, 2007).

Table 1. Drought categories according to Agnew's (2000) scheme.

\begin{tabular}{|l|c|}
\hline \multicolumn{1}{|c|}{ SPI values } & Drought category \\
\hline Less than 0 & No drought \\
\hline Less than -0.50 & Mild drought \\
\hline Less than -0.84 & Moderate drought \\
\hline Less than -1.28 & Severe drought \\
\hline Less than -1.65 & Extreme drought \\
\hline More than -1.65 & Very extreme drought \\
\hline
\end{tabular}

\subsection{PCA analysis}

To obtain more detailed knowledge of the spatial variability of drought at the subregional scale, principal component analysis (PCA) was used to identify homogenous spatial patterns. PCA is a multivariate variable-reduction procedure, which is commonly used in climate research for defining the leading spatial and temporal patterns of climate variability (Richman, 1986). Following this approach, the original "raw" intercorrelated variables are reduced to a few number of linear, non-correlated variables that explain most of the total variance (Santos et al., 2010). In hydrometeorology research, PCA has been used for the regionalization of climate variables and phenomenon at different spatial and temporal scales, including precipitation (e.g. Llasat et al., 2007), temperature (e.g., El Kenawy et al., 2013), evapotranspiration (e.g., Guanghui et al., 2011), snow depth (e.g., Dedieu et al., 2014) and drought (e.g., Santos et al., 2010; Vicente-Serrano et al., 2015a), in addition to classification of synoptic weather types (e.g., Peters and Schumacher, 2014) and air masses (e.g., Bejaran and Camilloni, 2003). In this research, an S-mode of the PCA was applied for temporal association among SPI time series calculated for 405 grid points over Ethiopia. According to this procedure, the time series of SPI at various grid 
points were used as variables in PCA. The aim was to maintain the empirical orthogonal functions (EOFs) that explain the dominant long-term (1960-2013) components and their spatial patterns across the region. Here, we followed the Kaiser stopping rule (i.e., eigenvalues greater or equal to 1.0) (Kaiser, 1960), only keeping the components with valuable and independent information. To verify the outputs of the Kaiser rule, we also applied Veelicer's Minimum Average Partial (MAP) test, which is based on the average partial correlations between the variables after iteratively removing the effect of the factors. The number of factors from the data that minimizes the (squared) average partial a correlation was just retained (Wilks, 2011). The defined components were rotated by means of the varimax orthogonal technique to reduce data dimensionality and capture the maximum variability in the input data. The rotation procedure is common to simplify the structure of the patterns by producing physically distinct patterns, with a clearer division between the retained components (Richman, 1986). Grid points were assigned to factors based on their maximum factor loadings (correlations). Here, a 0.6 threshold was used as a cutoff loading. The isopleths of the computed PCA loadings were also mapped to give insights into the spatial variability of the obtained drought components. Finally, a least squares method was used to assess long-term trends and periodic behavior in the SPI frequency series corresponding to the significant components. In particular, the analysis was performed for the SPI time series averaged for each particular region, as suggested by the PC patterns. The non-parametric Spearman Rho was used to assess the significance of the trend at a confidence interval of $95 \%$ ( $\mathrm{p}$ value $<0.05$ ). Rho has been widely employed in the climatological and hydrological applications, as it is robust to outliers and does not assume prior probability distribution of the residuals (Arismendi et al., 2012).

\section{Results}

\subsection{Changes in drought intensity}

Figure 3 illustrates the temporal evolution of the SPI, averaged over 405 grid cells, across Ethiopia between 1960 and 2013. Overall, z-unit values suggest that the relative frequency of dry $(\mathrm{SPI}<0)$ and wet $(\mathrm{SPI}>0)$ months is almost equal, with 48.8 and $51.2 \%$ of all months, respectively. A linear trend analysis applied to a 60 -month moving average of the SPI regional series suggests a significant decline in the frequency of drought over the study period $(-0.16 \mathrm{Z}$-unit per decade, $\mathrm{p}<0.01)$. Nonetheless, there is a pronounced intra-decadal variation in the frequency of dry and wet episodes. Results reveal that the dry periods were less intense in the 1960s and 1970s, followed by a general dry period that extended from the beginning of the 1980s until the mid 2000s. The most intense drought episodes were recorded in 1984, 1985 and 1988 and between 2002 and 2004. Some exceptional drought events occurred, especially in May-June 1988 (SPI<-2.8) and October-December 1984 (SPI <-2.5). In contrast, typical wet periods were recorded between January and June of 1968 (SPI >3.1) and between November 1961 and March 1962 (SPI>2.5). Overall, results indicate that intense droughts characterized more the cold period (October-March) of the year, compared to the warm period (April-September). The mean duration of a consecutive period of dry months was 7.6 months. The maximum 
length of dry months was 42, extending between September 2001 and February 2005, although droughts during this horizon were generally mild or moderate (SPI <-0.9). Another notable extended dry period was found between May 1990 and April 1993. On the other hand, the mean duration of the wet episodes was 7.8 months, with the longest extended wet period occurring between May 1967 and August 1969 (28 months), and between April 1963 and June 1965 (27 months).

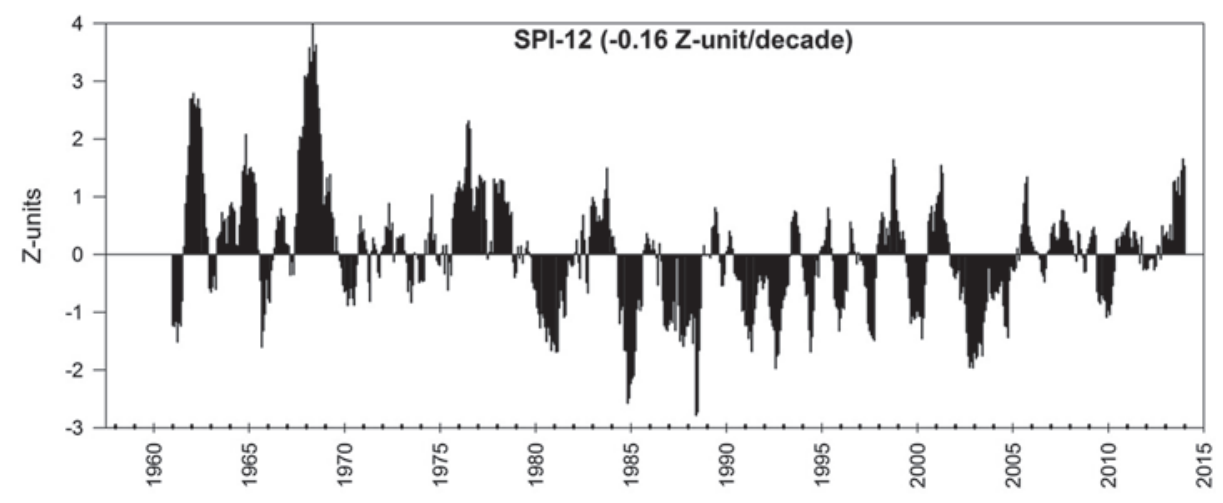

Figure 3. Evolution of the regional SPI-12months over Ethiopia during the period 1960-2013. The cumulative probability gamma function of precipitation was transformed into a standard normal random variable, expressed in Z-units, with mean of zero and standard deviation of one. Changes in the SPI over the period 1960-2013 are also provided for the regional SPI series (Z-unit per decade), using a moving average of 10 years.

Figure 4 presents the temporal evolution of the area corresponding to each specified drought category following the Agnew (2000) scheme. Results indicate that, during some periods, more than $90 \%$ of the study domain were not affected by any category of drought classification (i.e., SPI>0). This pattern was mainly observed during the $1960 \mathrm{~s}$ (e.g., 1964, 1967 and 1968). In contrast, the drought episode in October-December 1984 was the most drastic and distinct-wide dry episode over the last five decades, as it swept more than $95 \%$ of the entire domain. Among them, $39.6 \%$ of the country were affected by very extreme droughts, compared to $20.7 \%$ for extreme droughts, $15.4 \%$ for severe droughts, $8.5 \%$ for moderate droughts and $8.3 \%$ for mild droughts. An inspection of all drought categories indicates that mild drought $(\mathrm{SPI}<-0.5)$ was the dominant drought category, affecting -on average- $20.5 \%$ of the country over the 54-year period. In contrast, the moderate, severe, extreme and very extreme droughts were less distributed over space, affecting just $10.8,9.9,4.9$ and $4.2 \%$ of the total surface, respectively. The most widespread mild drought occurred in January-May 2004, covering almost 50\% of the entire area, followed by the episode of October-December 2003 (40\%). Figure 4 also shows that the number of mild drought events affecting more than $40 \%$ of the area was restricted to the last decade (e.g., 2003, 2004, 2006, 2009 and 2011). In contrast, the areas affected by moderate drought were less spread during recent decades, relative to 
earlier decades. The moderate droughts of November-December 1991, January-February 1996 and between December 2009 and February 2010 were the most widespread moderate episodes, covering almost $25 \%$ of the entire area. With few exceptions, more than $30 \%$ of the country was under very extreme drought threat (SPI>-1.65). Among them, the August-December dry episode of 1984 and that of May-June 1988 pointed to exceptionally widespread and intense droughts. The analysis implies that drought intensity can vary considerably over space and that these exceptionally extreme droughts show a local character, where small areas were affected, while others had a less severe drought intensity or even no drought.
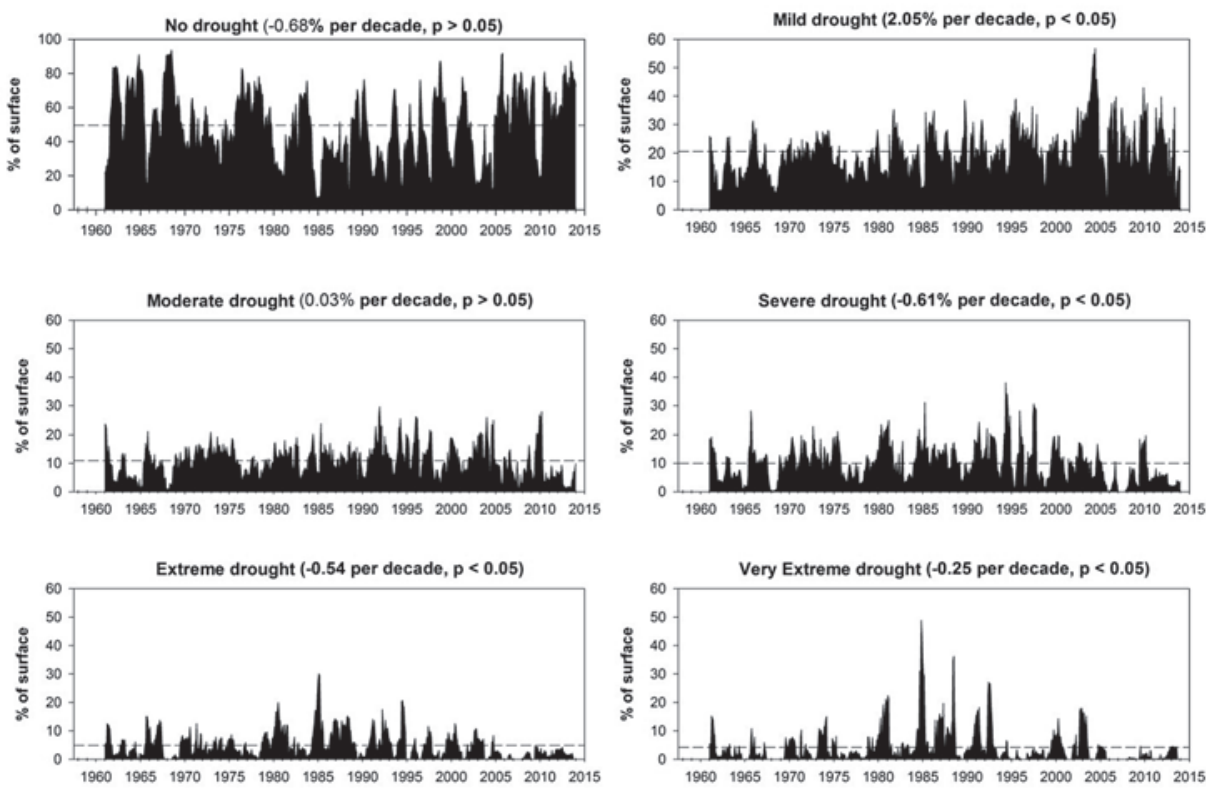

Figure 4. Temporal evolution of the surface impacted by droughts of different intensity over Ethiopia, following Agnew scheme (2000). The confidence interval for the observed changes is provided for each drought category. Only significant changes are given in bold. The central dotted line indicates the mean of the affected surface over the entire period of investigation.

Results on the temporal evolution of each drought category from 1960 to 2013 suggest that statistically significant changes $(\mathrm{p}<0.05)$ were found for all drought categories, except for moderate droughts. Nonetheless, these significant changes showed a different sign of change (Figure 4). In particular, while areas dominated by mild droughts exhibited a statistically significant increase $(2.05 \%$ per decade) in its surface over the 54-year period, the total area impacted by severe, extreme and very extreme droughts showed a significant decline on the order of $-0.61,-0.54$ and $-0.25 \%$ per decade, respectively. The increase in areas affected by moderate droughts was not significant at the $95 \%$ confidence interval. A comparison of Figures 2 and 3 suggests that the decrease 
in the frequency of drought in recent decades, as revealed by the regional series of SPI, can be linked to the statistically negative changes in the frequency of droughts of higher intensity (i.e., severe, extreme and very extreme) rather than changes in the frequency of mild and moderate droughts. Under climate change conditions, this result may raise a question whether changes in the upper tail of precipitation distribution over the region follow the same rates of changes of the mean values of precipitation. In this respect, our findings suggest that the shift in the precipitation distribution may be inconsistent over the region, with rapid changes in the mean conditions rather than changes in the upper percentiles of the distribution. This could explain why changes in the mild drought events, which are more associated with changes in the moderate percentiles, are more pronounced compared to severe droughts that are linked particularly to changes in the upper percentiles.

\subsection{Spatial Variability of Droughts}

In order to define the leading temporal components of drought variability and their associated spatial patterns over the study region, the SPI series calculated for the period 1960-2013, for 405 grid points, were used as inputs for the spatial domain of PCA (S-mode). As the SPI series represent normalized values following the index underlying concept, all series had an equal weight. For this reason, a data matrix based on the interseries correlation was obtained to characterize the dependency among the data. Following the results of the scree plot as well as Velicer's minimum average partial test (Figure 5), ten main patterns (EOFs) were retained, which together account for $72.9 \%$ of the total explained variance in the original SPI series. The spatial structure of the identified components was plotted using the values of the rotated factorial matrix (Figure 6). A correlation threshold of 0.6 between each component and the SPI series at the 405 grid points was applied. As illustrated in Figure 6, the defined regions are spatially distinct. Overall, the number of retained components as well as the small variance explained by each of them suggests a high spatial variability of drought over Ethiopia. Specifically, apart from component 1 , the remaining components explained a small percentage of variance (less than $9 \%$ for each), suggesting that these components represent more localized spatial patterns of SPI. In other words, it is common over the study domain to have extremely wet areas during specific periods, while other areas are in drought conditions. Overall, component 1 explained the largest proportion of the total variance (19.03\%), with higher loadings (correlations) over the lowlands located in the southeast (Somalia province). The higher amount of variance explained by this component, relative to other components, may imply that this region is more vulnerable to frequent cycles of hydrological droughts (SPI at 12 months scale). The second component explained $8.81 \%$ of the total variance, reflecting the wet/dry conditions in Afar region northeast. The correlations among the values of component 3 and SPI series were much higher in Tigray province northward. On the other hand, component 4 represents southern areas of Oromia province. Hydrologically, the first four components, which explained together $42.29 \%$ of the total variance, are spatially associated with the most arid zones (150$450 \mathrm{~mm} /$ year) over Ethiopia. In contrast, the behivour of drought in the highly elevated 
humid zones are best described by components 6 and 10, which are distributed across the central regions of the Ethiopian Highlands.

(a) Scree plot

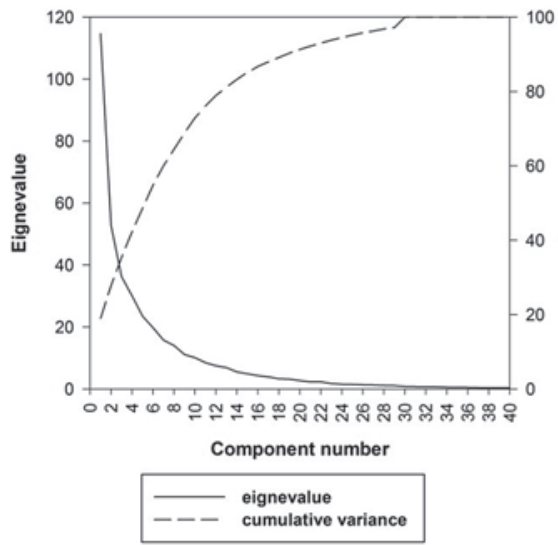

(b) Velicer's Minimum Average Partial (MAP) test

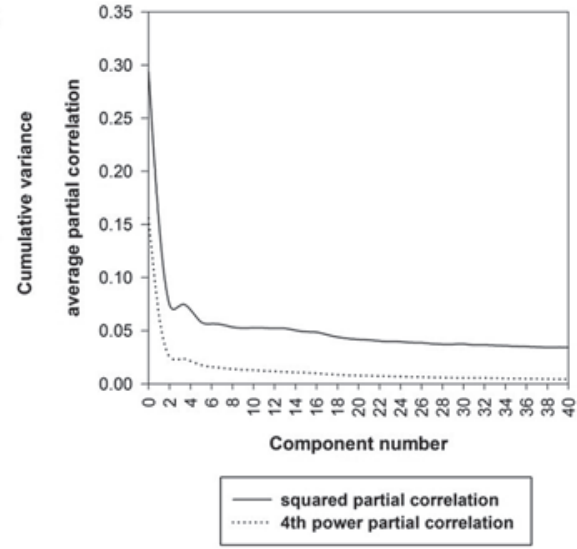

Figure 5. (a) Scree plot and (b) Velicer's minimum average partial test showing the number of selected components.
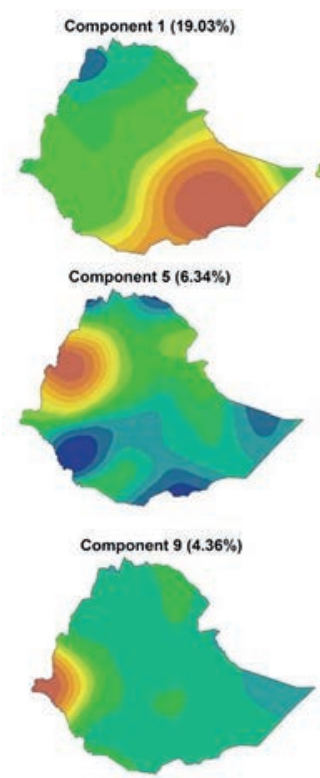
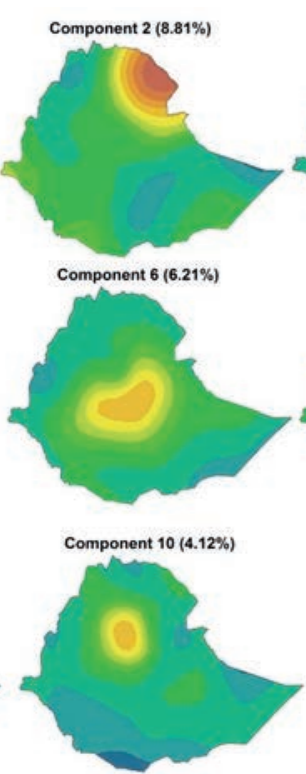
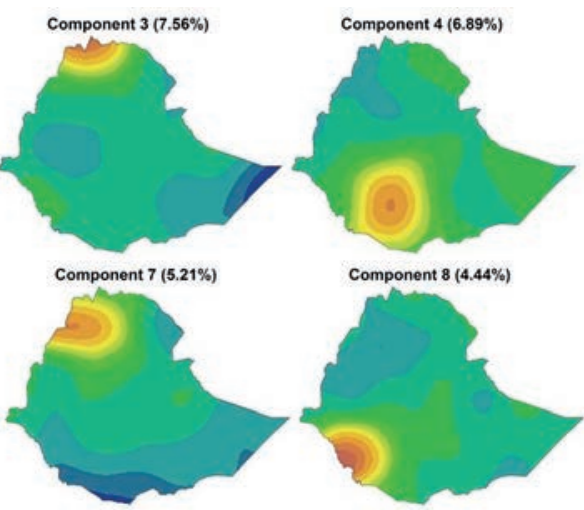

Figure 6. Spatial distribution of the rotated empirical orthogonal functions (EOFs) from PCA of the SPI series. Numbers between parentheses indicate the amount of variance explained by each component. 
Figure 7 depicts the temporal evolution of the SPI series and their corresponding trends (Z-unit per decade) for the identified EOFs. Overall, the majority of the historical droughts that occurred in the study region were of mild and moderate severity. As illustrated, there are large differences in the wet and dry pattern among the different components, suggesting high spatial and temporal variability of drought across the region. The southeastern regions that express the first component were generally characterized by mild and moderate droughts (SPI<-0.84). In few exceptions, this region suffered particularly from very extreme droughts (SPI>-1.65), such as the prolonged drought episodes in April-August 1992. For component 1 , the 1980 s and 1990s were the driest decades, while the 1960s and 1970s were the wettest decades on record. The peaks of the wet conditions were found from February to July 1968, with SPI values exceeding 2.5. In the Afar region (component 2), stronger multi-decadal variations of SPI values were observed, where earlier decades (1960s and 1970s) were more humid, while large magnitude droughts were usually centered in the 1980s and 1990s. The most drastic drought episode in Afar region corresponds to the period from July 1984 to March 1985, in which the SPI values exceeded -2.1. Another distinct extreme drought episode was found between May and June 1988. Conversely, the last decade exhibited mild, wet periods, with almost no distinct dry episodes. For Tigray region in northern Ethiopia (component 3), the temporal evolution of SPI shows significant differences, compared to the first two components. In particular, prolonged wet conditions predominated over the Tigray region (SPI $>1.5$ ) from 1975 to 1985 , which does not coincide with the drastic dry episode spanning the first two components over the same period. In contrast, Tigray region exhibited severe drought episode during the last decade, with SPI values ranging from -1.5 to -2: a pattern that is typically reversed for the first two components. Component 4 mainly affects the drought change in the southwestern Oromia region. Over the 54 years, the annual drought has more variations, with early 1960s and the last decade representing the wettest periods. Three periods dominated by dry conditions (1969-1974, 1984-1986 and 1999-2004) and wet conditions over 19601962 and 2005-2015. Notably, the northwestern Gumaz region (component 5) has become less drier in recent years. The climate is relatively dry in 1980s, 1990s and early 2000s. After 2006, it tends to be wet. Similar to other components, the temporal evolution of SPI corresponding to components $6,7,8,9$ and 10 was characterized by rainfall shortages during the period 1984-1987, while wet conditions prevailed in the last decade. The temporal analyses of 12-month SPI values show that component 8 (Oromia region) was predominantly characterized by more frequent mild droughts, relative to other components. Exceptionally, component 9 (Gambela region) exhibited drier episodes in the recent years, where the maximum 12-month SPI was observed in June 2009 (SPI =-1.85). In earlier decades, the behivour of drought showed large differences, as 1960s was generally wet in regions corresponding to components 6 and 9, while it was drier in regions associated with components 7,8 and 10 . 

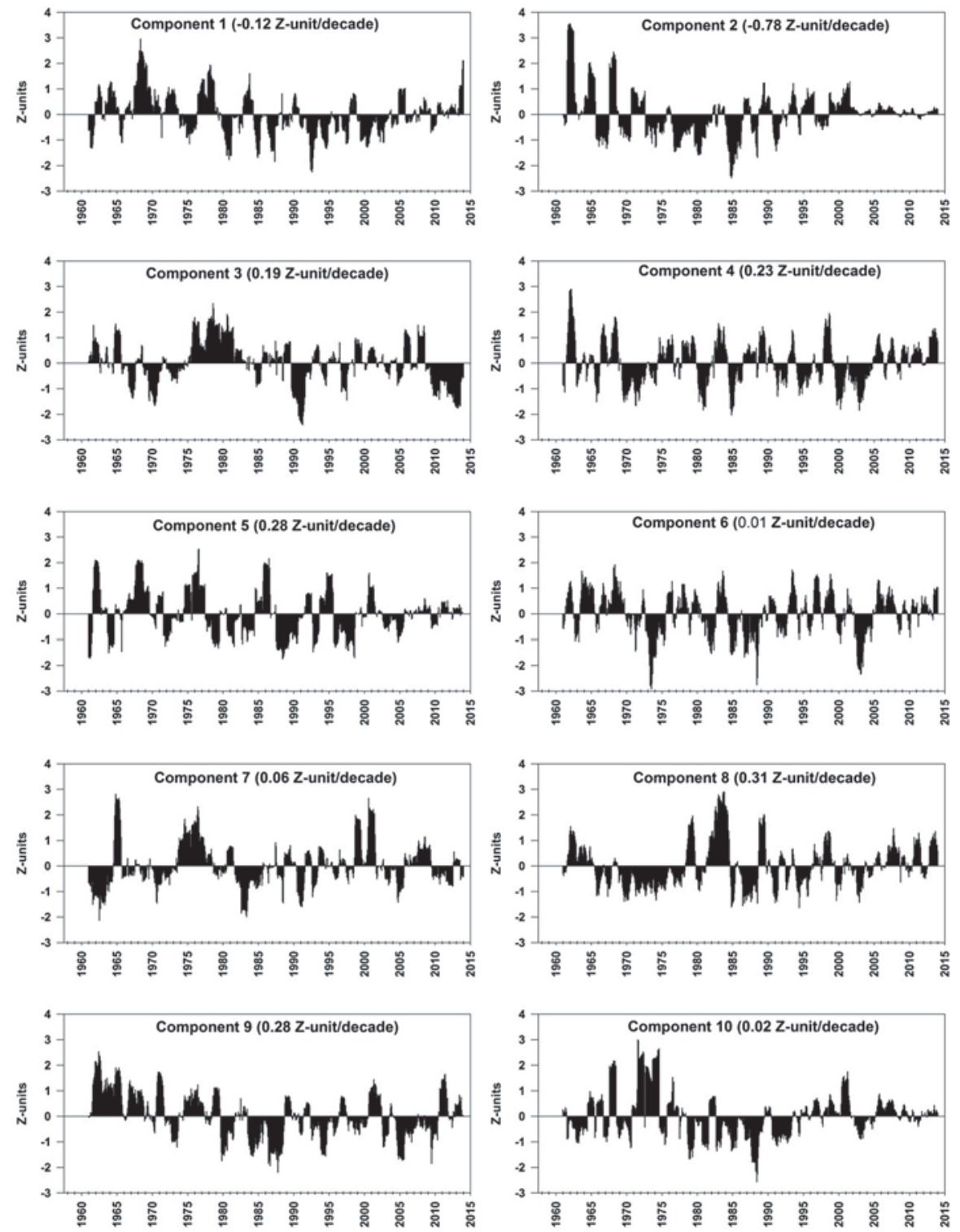

Figure 7. Temporal evolution of the ten components, extracted following the application of PCA to SPI series. Changes in the SPI time series over the period 1960-2013 are provided for each component and expressed in Z-unit per decade.

A comparison of the different components in terms of the duration of the drought episode shows some considerable results. The mean length of the drought episodes does 
not vary greatly among components, as it ranges between 7.9 months (component 3) and 13.1 consecutive months (component 10). In contrast, the highest duration of a dry episode varied considerably from one component to another, with the most prolonged drought (115 consecutive months) found in component 8 (Oromio province) between September 1968 and March 1978. Another exceptionally extended dry episode, with 83 consecutive months, was observed for component 10 (central highlands), which extended in the period from August 1982 to June 1989.

Figure 7 also illustrates the linear trends in the 12-month SPI over the period 1960-2013. Overall, the SPI values increased significantly in most regions of Ethiopia, suggesting a decrease in the severity of drought over the 54-year period. This finding indicates that most of the regions showed the same pattern of positive trend in SPI, which was consistent with the results for the whole country. However, the amounts of change exhibited a wide range of values, ranging between $0.01 \mathrm{Z}$-unit per decade (component 6 : central highlands) and $0.31 \mathrm{Z}$-unit per decade (component 8: Southern Nations province). The first two components, which accounted for the largest proportion of the explained variance $(19.03 \%)$, showed a dry trend, implying that these regions exhibited a large increase in dryness over the investigated period. However, the largest decrease in SPI was seen in Afar region (-0.78 Z-unit per decade), compared to the lowlands in the southeast (-0.12 Z-unit per decade). Interestingly, the lowest increase in SPI values was found over the most humid and topographically complex regions across the central areas of the Ethiopian Highlands (components 6 and 10), relative to other drier and low elevated areas. Importantly, an inspection of Figure 7 suggests that the strong dryness in the 1980s and 1990s significantly accounted for the observed negative trend in SPI values over the entire period, suggesting a strong inter-decadal variations in drought evolution over these two regions. This is particularly because these two components exhibited a decrease in dryness conditions after 2005.

\section{Discussion and conclusions}

Here we assessed the drought patterns over Ethiopia from 1960 to 2013. Based on the CRU 3.22 monthly gridded precipitation data set for 405 grid points across the country, the Standardized Precipitation Index (SPI) was computed on a 12-months timescale for each grid point. Results indicate that the study domain experienced a decline drying trend on the order of $-0.16 \mathrm{Z}$-unit per decade. In particular, less severe droughts were observed in the last decades, particularly from 2005 onwards, compared to earlier decades (1980s and 1990s). This finding agrees well with previous works over Ethiopia (e.g., Beltrando and Camberlin, 1993; Bewket and Conway, 2007; Edossa et al., 2010; Viste et al., 2013). For example, apart from spring droughts, Viste et al. (2003) observed a decrease in the frequency of droughts over Ethiopia from 1971 to 2010 on annual, seasonal and biannual timescales. The significant decline in the severity of droughts over the 54-year period can partially be linked to the decline in the amount of of precipitation, though being statistically insignificant over the majority of the Ethiopian territory (Seleshi and Zanke, 2004; Viste et al., 2013). According to Seleshi and Zanke (2004), there is no trend in either the seasonal or annual rainfall totals over central, northern and 
northwestern Ethiopia for the period 1965-2002. Similarly, Conway (2000) found no recent trends in rainfall amounts over the northeastern Ethiopian Highlands. Significant decline was observed only for the annual and the June-September total rainfalls across the eastern, southern and southwestern regions. According to this study, the declining trend was more pronounced from 1982 onwards, suggesting a particular influence of the enhanced warm El Niño-southern oscillation episodes. In the same regard, Shanko and Camberlin (1998) attributed the humid conditions in Ethiopia during recent decades to the years of exceptionally low frequency of tropical cyclones. Similarly, Viste et al. (2013) noted that the southern region in Ethiopia is the only region, which exhibited a significant decrease in precipitation over the last four decades (at the $95 \%$ confidence level). Given the likelihood of increased air temperatures $\left(0.28^{\circ}\right.$ per decade $)$ in the region in recent decades (McSweeney et al., 2007; Conway and Schipper, 2011), our results could highlight a possible impact of temperature variability on drought evolution in the region, particularly for meteorological droughts. This dependency is still lacking and needs further investigation at a detailed spatial scale over Ethiopia. In this regard, some drought indices that account for the joint influence of temperature and precipitation on drought characteristics (e.g., the Standardized Precipitation Evapotranspiration Index [SPEI], Vicente Serrano et al., 2010) can be exploited to assess the role of temperature variations on drought development across the region.

Our findings also suggest that all zones experienced some degree of drought at the annual scale. The most severe or extreme droughts occurred in the period from 1984 to 1988. The proportional area affected by mild and severe droughts showed a statistically negative trend over the 54-year period. The areas subjected to the droughts of high intensity (i.e., extreme and very extreme) also exhibited a statistically significant decrease $(\mathrm{p}<0.05)$, with the peak of the decline occurring mostly in the 1990s and 2000s. In contrast, changes were only statistically insignificant for moderate droughts $(\mathrm{SPI}<-0.84 ; \mathrm{p}>0.05)$. These finding imply that the decrease in the frequency of drought in the recent decades is associated more with the decrease in the frequency of intense drought episodes, relative to moderate droughts. Our analysis also indicates that a non-synchronous occurrence of drought episodes over the country, where some severe drought episodes were witnessed in specific periods, while there were no droughts corresponding to these episodes across other regions of the study domain.

The general evolution of drought was obtained by means of the rotated empirical orthogonal function (REOF). Results of the PCA analysis revealed a high spatial heterogeneity in the SPI variations over the investigated period, with ten components explaining $72.9 \%$ of drought variability across the region. These patterns are related to distinct geographical areas and are associated with distinct temporal variations. It is observed that there is a strong relationship between the rainfall distribution and drought potential zones in the region, where the most significant patterns of drought were specifically found over the most arid zones, while less significant patterns were observed over the most humid regions. Overall, there are two spatially-broad components, which are distributed over the low elevated areas in the southeast (Somalia province) and the north (Afar province). These two components accounted for $27.9 \%$ of the variance. The first broad zone extends over arid, low elevated and agro pastoral lands in the 
southeast (Gebrehiwot et al., 2011), while the second zone is located in Afar region, in a semi-arid zone stretching from the northern slopes of the Ethiopian Highlands. These regions are the most vulnerable to recurrent droughts over Ethiopia. The remaining components explained a reduced level of variance (generally less than $9 \%$ of variability for each component), suggesting a more localized pattern of drought evolution. This finding is supported by Gebrehiwot et al. (2011) in their evaluation of the spatial and temporal characteristics of meteorological and vegetative drought in Tigray (Northern Ethiopia). They concluded that eastern and southern zones of the Tigray province suffered a recurrent cycle of drought over the last decade, compared to northern and western areas. Such spatial inhomogeneity can be viewed in the context of climate diversity, strong seasonality of precipitation, complex topography and soil types over Ethiopia. For example, winter precipitation is more important in southwestern lowlands, while summer precipitation is important over central and western areas (Seleshi and Zanke, 2004). Based on a comprehensive Austrian data set consisting of 44 catchments, Van Loon and Laaha (2015) concluded that drought duration and severity are largely governed by a combination of climate and catchment control (e.g., meteorological forcing, soils, topographic slope, elevation, etc.). In this regard, an investigation of the influence of geographic factors (e.g., elevation, distance to closing water bodies, slope and vegetation cover) on regional variability of drought could provide an avenue for future research. Given the local character of drought over the majority of the region, a detailed assessment of this dependency at a regional scale can properly characterize the drought phenomenon, providing evidence for policy makers to adopt appropriate policies to the risks of drought at local scale. Further assessments may also extend to evaluate the dependency between the spatial components of drought and large-scale atmospheric teleconnections. The atmospheric processes accounting for spatial and temporal changes in drought over Ethiopia can include the tropical configurations over the Atlantic as well as the Indian Ocean. These teleconnections can explain variations in the advection and transport of moisture to the study domain.

This study also assessed changes in the severity of droughts for the identified EOFs. Our findings suggest a statistically significant decrease $(p<0.05)$ in the severity of droughts for most regions, implying that many areas witnessed an increase in wetness during the 54-year study period. Nonetheless, results also indicate that the evolution of drought in Ethiopia is mainly linked to the distinct progression of this phenomenon between two specific regions: the southeast lowlands and Afar region. These regions accounted for $27.9 \%$ of the explained variance in SPI over the study period. Hydrologically, these two regions correspond with the most arid climate zones in Ethiopia, with annual precipitation generally below 400mm. Our results indicate that these arid regions exhibited the largest decrease in SPI over Ethiopia, on the order of -0.12 and -0.78 Z-unit per decade for the southeast and Afar regions, respectively. This finding is important given the low precipitation over these regions on one hand, and their heavy dependence on irrigation for agriculture on the other hand. Accordingly, these regions are highly sensitive to rainfall fluctuations and even a slight change could induce significant influences on the socio-economic activities in the region. Meze- 
Hausken (2004) found that many farms have shifted to more drought-resistant crops in northern Ethiopia, as a consequence of the decline in rainfall during the last decades.

Assessing the spatial and temporal extent of droughts in Ethiopia, a country that is prone to recurrent drought episodes, is crucial to understand the possible impacts of this natural hazard on agriculture, food production, soil degradation, human settlements and migrations, energy production and water resources management. The negative impacts of prolonged and intense droughts over Ethiopia may create political instability and regional conflicts, given that the Ethiopian tributaries contribute to the vast majority of the Nile discharge. Access to water resources is generally limited in the countries lying at the lower catchment of the Nile (e.g., Sudan and Egypt), which further challenges water resources monitoring, planning and policy in the entire basin. These problems are likely to grow in the future under current population projections, higher water demands and enhanced climate change.

\section{Acknowledgements}

Research reported in this publication was supported by the King Abdullah University of Science and Technology (KAUST), Saudi Arabia. We wish to thank the Climate Research Unit (CRU) at the University of East Angelia (UK) for providing their data.

\section{References}

Agnew, C.T. (2000). Using the SPI to identify drought. Drought Network News, 12 (1), 6-12.

Antwi-Agyei, P., Fraser, E.D.G., Dougill, A.J., Stringer, L.C., Simelton, E. 2012. Mapping the vulnerability of crop production to drought in Ghana using rainfall, yield and socioeconomic data. Applied Geography 32 (2), 324-334. Doi: 10.1016/j.apgeog.2011.06.010.

Arismendi, I., Johnson, S.L., Dunham, J.B., Haggerty, R., Hockman-Wert, D. 2012. The paradox of cooling streams in a warming world: Regional climate trends do not parallel variable local trends in stream temperature in the Pacific continental United States. Geophysical Research Letters 39 (10). Doi: 10.1029/2012GL051448.

Bejarán, R.A., Camilloni, I.A. 2003. Objective method for classifying air masses: an application to the analysis of Buenos Aires' (Argentina) urban heat island intensity. Theoretical and Applied Climatology 74 (1-2), 93-103. Doi: 10.1007/s00704-002-0714-4.

Beltrando, G., Camberlin, P. 1993. Interannual variability of rainfall in the eastern horn of Africa and indicators of atmospheric circulation. International Journal of Climatology 13 (5), 533 546. Doi: 10.1002/joc.3370130505.

Bewket, W., Conway, D. 2007. A note on the temporal and spatial variability of rainfall in the drought-prone Amhara region of Ethiopia. International Journal of Climatology 27 (11), 1467-1477. Doi: 10.1002/joc.1481.

Boken, V.K. (2009). Improving a drought early warning model for an arid region using a soilmoisture index. Applied Geography 29 (3), 402-408. Doi: 10.1016/j.apgeog.2008.12.006.

Bonaccorso, B., Bordi, I., Cancelliere, A., Rossi, G., Sutera, A. 2003. Spatial Variability of Drought: An Analysis of the SPI in Sicily. Water Resources Management 17 (4), 273-296. Doi: 10.1023/A:1024716530289.

Brando, P.M., Balch, J.K., Nepstad, D.C., Morton, D.C., Putz, F.E., Coe, M.T., Soares-Filho, B.S. 2014. Abrupt increases in Amazonian tree mortality due to drought-fire interactions. Proceedings of the National Academy of Sciences 111 (17), 6347-6352. Doi: 10.1073/ pnas.1305499111. 
Burke, M.B., Miguel, E., Satyanath, S., Dykema, J.A., Lobell, D.B. 2009. Warming increases the risk of civil war in Africa. Proceedings of the National Academy of Sciences 106 (49), 20670-20674. Doi: 10.1073/pnas.0907998106.

Conway, D. 2000. Some aspects of climate variability in the north east Ethiopian Highlands Wollo and Tigray. SINET - Ethiopian Journal of Science 23, 139-161.

Conway, D., Schipper, E.L.F. 2011. Adaptation to climate change in Africa: Challenges and opportunities identified from Ethiopia. Global Environmental Change 21, 227-237.

Dai, A. 2011. Drought under global warming: a review. Wiley Interdisciplinary Reviews: Climate Change 2 (1), 45-65. Doi: 10.1002/wcc.81.

Dai, A. 2013. Increasing drought under global warming in observations and models. Nature Climate Change 3 (1), 52-58.

Dedieu, J.P., Besic, N., Vasile, G., Mathieu, J., Durand, Y., Gottardi, F. 2014. Dry snow analysis in alpine regions using RADARSAT-2 full polarimetry data. Comparison with in situ measurements. Paper presented at the Geoscience and Remote Sensing Symposium (IGARSS), 2014 IEEE International.

Deng, L., McCabe, M.F., Stenchikov, G., Evans, J.P. Kucera, P.A. 2015. Simulation of flash-floodproducing storm events in Saudi Arabia using the weather research and forecasting model. Journal of Hydrometeorology 16 (2), 615-630. Doi: 10.1175/JHM-D-14-0126.1.

Diro, G.T., Black, E., Grimes, D.I.F. 2008. Seasonal forecasting of Ethiopian spring rains. Meteorological Applications 15 (1), 73-83. Doi: 10.1002/met.63.

Edossa, D., Babel, M., Das Gupta, A. 2010. Drought Analysis in the Awash River Basin, Ethiopia. Water Resources Management 24 (7), 1441-1460. Doi: 10.1007/s11269-009-9508-0.

El Kenawy, A., López-Moreno, J.I., Vicente-Serrano, S. 2013. Summer temperature extremes in northeastern Spain: spatial regionalization and links to atmospheric circulation (1960-2006). Theoretical and Applied Climatology 113 (3-4), 387-405. Doi: 10.1007/s00704-012-0797-5.

El Kenawy, A.M., McCabe, M.F. 2015. A multi-decadal assessment of the performance of gaugeand model-based rainfall products over Saudi Arabia: climatology, anomalies and trends. International Journal of Climatology. Doi: 10.1002/joc.4374.

Funk, C., Dettinger, M.D., Michaelsen, J.C., Verdin, J.P., Brown, M.E., Barlow, M., Hoell, A. 2008. Warming of the Indian Ocean threatens eastern and southern African food security but could be mitigated by agricultural development. Proceedings of the National Academy of Sciences 105 (32), 11081-11086. Doi: 10.1073/pnas.0708196105.

Gebrehiwot, T., van der Veen, A., Maathuis, B. 2011. Spatial and temporal assessment of drought in the Northern highlands of Ethiopia. International Journal of Applied Earth Observation and Geoinformation 13 (3), 309-321. Doi: 10.1016/j.jag.2010.12.002.

Griffiths, J.F. (1972). Climates of Africa. World Survey of Climatology, 10, Elsevier, Amsterdam.

Guanghui, W., Xinguang, D., Anyan, H. 2011. Discuss on reference crop evapotranspiration in arid zone based on principal component analysis. Paper presented at the International Symposium on Water Resource and Environmental Protection (ISWREP), 2011.

Harris, I., Jones, P.D., Osborn, T.J., Lister, D.H. 2014. Updated high-resolution grids of monthly climatic observations - the CRU TS3.10 Dataset. International Journal of Climatology 34 (3), 623-642. Doi: 10.1002/joc.3711.

Hirschi, M., Seneviratne, S.I., Alexandrov, V., Boberg, F., Boroneant, C., Christensen, O.B., Stepanek, P. 2011. Observational evidence for soil-moisture impact on hot extremes in southeastern Europe. Nature Geosciences 4 (1), 17-21.

Hoerling, M., Hurrell, J., Eischeid, J., Phillips, A. 2006. Detection and Attribution of TwentiethCentury Northern and Southern African Rainfall Change. Journal of Climate 19 (16), 39894008. Doi: 10.1175/JCLI3842.1.

Hunt, E.D., Svoboda, M., Wardlow, B., Hubbard, K., Hayes, M., Arkebauer, T. (2014). Monitoring the effects of rapid onset of drought on non-irrigated maize with agronomic data and climatebased drought indices. Agricultural and Forest Meteorology 191, 1-11. Doi: 10.1016/j. agrformet.2014.02.001. 
Ji, L., Peters, A.J. 2003. Assessing vegetation response to drought in the northern Great Plains using vegetation and drought indices. Remote Sensing of Environment 87 (1), 85-98. Doi: 10.1016/S0034-4257(03)00174-3.

Kaiser, H.F. 1960. The application of electronic computers to factor analysis. Educational and Psychological Measurement 20, 141-151.

Korecha, D., Barnston, A.G. 2007. Predictability of June-September Rainfall in Ethiopia. Monthly Weather Review 135 (2), 628-650. Doi: 10.1175/MWR3304.1.

Livneh, B., Bohn, T.J., Pierce, D.W., Muñoz-Arriola, F., Nijssen, B., Vose, R., Brekke, L. 2015. A spatially comprehensive, hydrometeorological data set for Mexico, the U.S., and Southern Canada 1950-2013. Scientific Data 2, 150042. Doi: 10.1038/sdata.2015.42.

Llasat, M.C., Ceperuelo, M., Rigo, T. 2007. Rainfall regionalization on the basis of the precipitation convective features using a raingauge network and weather radar observations. Atmospheric Research 83 (2-4), 415-426. Doi: 10.1016/j.atmosres.2005.08.014.

Lloyd-Hughes, B., Saunders, M.A. 2002. A drought climatology for Europe. International Journal of Climatology 22 (13), 1571-1592. Doi: 10.1002/joc.846.

McKee, T.B., Doeskin, N.J., Kleist, J. (1993). The relationship of drought frequency and duration to time scales. Paper presented at the 8th Conf. on Applied Climatology, Anaheim, Canada.

Meinke, H., deVoil, P., Hammer, G.L., Power, S., Allan, R., Stone, R.C., Potgieter, A. 2005. Rainfall Variability at Decadal and Longer Time Scales: Signal or Noise? Journal of Climate 18 (1), 89-96. Doi: 10.1175/JCLI-3263.1.

Meze-Hausken, E. 2004. Contrasting climate variability and meteorological drought with perceived drought and climate change in northern Ethiopia. Climate Research 27 (1), 19-31. Doi: $10.3354 / \mathrm{cr} 027019$.

Mishra, A.K., Singh, V.P. 2010. A review of drought concepts. Journal of Hydrology 391 (1-2), 202-216. Doi: 10.1016/j.jhydrol.2010.07.012.

McSweeney, C., New, M., Lixcano, G. 2007. Ethiopia. UNDP Climate Change Country Profiles report.

Ngongondo, C., Xu, C.Y., Gottschalk, L., Alemaw, B. 2011. Evaluation of spatial and temporal characteristics of rainfall in Malawi: a case of data scarce region. Theoretical and Applied Climatology 106 (1-2), 79-93. Doi: 10.1007/s00704-011-0413-0.

Ntale, H.K., Gan, T.Y. 2003. Drought indices and their application to East Africa. International Journal of Climatology 23 (11), 1335-1357. Doi: 10.1002/joc.931.

Peel, M.C., Finlayson, B.L., McMahon, T.A. 2007. Updated world map of the Köppen-Geiger climate classification. Hydrology and Earth System Sciences 11 (5), 1633-1644. Doi: 10.5194/hess-11-1633-2007.

Peters, J.M., Schumacher, R.S. (2014). Objective Categorization of Heavy-Rain-Producing MCS Synoptic Types by Rotated Principal Component Analysis. Monthly Weather Review 142 (5), 1716-1737. Doi: 10.1175/MWR-D-13-00295.1.

Quiring, S.M. 2009. Developing Objective Operational Definitions for Monitoring Drought. Journal of Applied Meteorology and Climatology 48 (6), 1217-1229. Doi: 10.1175/2009JAMC2088.1.

Ren, L., Arkin, P., Smith, T.M., Shen, S.S.P. 2013. Global precipitation trends in 1900-2005 from a reconstruction and coupled model simulations. Journal of Geophysical Research: Atmospheres 118 (4), 1679-1689. Doi: 10.1002/jgrd.50212.

Richman, M.B. 1986. Rotation of principal components. Journal of Climatology 6 (3), 293-335. Doi: $10.1002 /$ joc. 3370060305 .

Santos, J.F., Pulido-Calvo, I., Portela, M.M. 2010. Spatial and temporal variability of droughts in Portugal. Water Resources Research 46 (3). Doi: 10.1029/2009WR008071.

Schneider, T., Bischoff, T., Haug, G.H. 2014. Migrations and dynamics of the intertropical convergence zone. Nature 513 (7516), 45-53. Doi: 10.1038/nature13636.

Schonwiese, C.D., Rapp, J. 1997. Climate trend atlas of Europe based on observations 18911990. Kluwer Academic Publishers, Dordrecht, 228 pp.

Seleshi, Y., Zanke, U. 2004. Recent changes in rainfall and rainy days in Ethiopia. International Journal of Climatology 24 (8), 973-983. Doi: 10.1002/joc.1052. 
Shanko, D., Camberlin, P. 1998. The effects of the Southwest Indian Ocean tropical cyclones on Ethiopian drought. International Journal of Climatology 18 (12), 1373-1388. Doi: 10.1002/ (SICI)1097-0088(1998100)18:12<1373::AID-JOC313>3.0.CO;2-K.

Sheffield, J., Wood, E. 2008. Projected changes in drought occurrence under future global warming from multi-model, multi-scenario, IPCC AR4 simulations. Climate Dynamics 31 (1), 79-105. Doi: 10.1007/s00382-007-0340-z.

Sheffield, J., Wood, E.F., Chaney, N., Guan, K., Sadri, S., Yuan, X., Ogallo, L. 2014. A Drought Monitoring and Forecasting System for Sub-Sahara African Water Resources and Food Security. Bulletin of the American Meteorological Society 95 (6), 861-882. Doi: 10.1175/ BAMS-D-12-00124.1.

Sheffield, J., Wood, E.F. 2011. Drought: Past Problems and Future Scenarios. Routledge, 224 pp.

Sheffield, J., Wood, E.F., Roderick, M.L. 2012. Little change in global drought over the past 60 years. Nature 491 (7424), 435-438.

Stagge, J.H., Tallaksen, L.M., Gudmundsson, L., Van Loon, A.F., Stahl, K. 2015. Candidate Distributions for Climatological Drought Indices (SPI and SPEI). International Journal of Climatology 35 (13), 4027-4040. Doi: 10.1002/joc.4267.

Trenberth, K.E., Dai, A., van der Schrier, G., Jones, P.D., Barichivich, J., Briffa, K.R., Sheffield, J. 2014. Global warming and changes in drought. Nature Climate Change 4 (1), 17-22. Doi: 10.1038/nclimate2067.

Van Loon, A.F., Laaha, G. 2015. Hydrological drought severity explained by climate and catchment characteristics. Journal of Hydrology 526, 3-14. Doi: 10.1016/j.jhydrol.2014.10.059.

Vicente-Serrano, S.M. 2006. Differences in Spatial Patterns of Drought on Different Time Scales: An Analysis of the Iberian Peninsula. Water Resources Management 20 (1), 37-60. Doi: 10.1007/s11269-006-2974-8.

Vicente-Serrano, S.M., Cuadrat-Prats, J.M. 2007. Trends in drought intensity and variability in the middle Ebro valley (NE of the Iberian peninsula) during the second half of the twentieth century. Theoretical and Applied Climatology 88 (3-4), 247-258. Doi: 10.1007/s00704-0060236-6.

Vicente-Serrano, S.M., Beguería, S., Gimeno, L., Eklundh, L., Giuliani, G., Weston, D., Pegram, G.G.S. 2012. Challenges for drought mitigation in Africa: The potential use of geospatial data and drought information systems. Applied Geography 34, 471-486. Doi: 10.1016/j. apgeog. 2012.02.001.

Vicente-Serrano, S.M., Beguería, S., López-Moreno, J.I. 2010. A Multiscalar Drought Index Sensitive to Global Warming: The Standardized Precipitation Evapotranspiration Index. Journal of Climate 23 (7), 1696-1718. Doi: 10.1175/2009JCLI2909.1.

Vicente-Serrano, S.M., Chura, O., López-Moreno, J.I., Azorin-Molina, C., Sánchez-Lorenzo, A., Aguilar, E., Nieto, J.J. 2015a. Spatio-temporal variability of droughts in Bolivia: 1955-2012. International Journal of Climatology 35 (10), 3024-3040. Doi: 10.1002/joc.4190.

Vicente-Serrano, S.M., Cabello, D., Tomás-Burguera, M., Martín-Hernández, N., Beguería, S., Azorín-Molina, C., Kenawy, A. 2015b. Drought Variability and Land Degradation in Semiarid Regions: Assessment Using Remote Sensing Data and Drought Indices (19822011). Remote Sensing 7 (4), 4391.

Viste, E., Korecha, D., Sorteberg, A. 2013. Recent drought and precipitation tendencies in Ethiopia. Theoretical and Applied Climatology 112 (3-4), 535-551. Doi: 10.1007/s00704-012-0746-3.

Westra, S., Alexander, L.V., Zwiers, F.W. 2013. Global Increasing Trends in Annual Maximum Daily Precipitation. Journal of Climate 26 (11), 3904-3918. Doi: 10.1175/JCLI-D-12-00502.1.

Wilks, D. 2011. Statistical Methods in the Atmospheric Sciences. Academic Press, Cornell University, Ithaca, New York, U.S.A.

Williams, A.P., Funk, C., Michaelsen, J., Rauscher, S., Robertson, I., Wils, T. G., Loader, N. 2012. Recent summer precipitation trends in the Greater Horn of Africa and the emerging role of Indian Ocean sea surface temperature. Climate Dynamics 39 (9-10), 2307-2328. Doi: 10.1007/s00382-011-1222-y. 